\title{
Resident Experiences with Journaling
}

\author{
Tara Sunder, MD, Gretchen Diemer, MD, and Vikas Sunder, MD
}

\section{BACKGROUND}

Each year, medical school graduates don their long white coat for the first time and begin their residency. While residency promises the excitement of learning and increased autonomy, it also brings long duty hours and stressful situations worsened by inexperience. Due to these stressors, burnout affects many residents each year. Studies have been done to see if wellness curricula help decrease resident burnout, and since journaling is a known way to relieve stress and enhance reflection, journaling has become a common intervention in these curricula. ${ }^{1,2}$ While there are studies evaluating the impact of journaling on mental health and stress relief, the data is still limited on journaling specifically in the resident population. The aim of this educational intervention is to expose internal medicine residents to journaling as a way to mitigate burnout and survey their responses to the intervention.

\section{METHODS}

Forty-six incoming, first year Internal Medicine residents at Thomas Jefferson University Hospital were given a journal during their residency orientation. Each week for 10 weeks, a writing prompt was sent via text message in one of four categories: creative fiction, gratitude, patient care, and personal reflection. Example prompts included: "What did you learn from a patient this week? What did you teach a patient this week? What is your goal for your next rotation?" In addition to the prompt, there was also a link to a short survey (Table 1) that assessed response rate, journaling beyond the prompt, and current clinical rotation. Additionally, burnout was measured via a two-question burnout index in the survey based on the Maslach Burnout Inventory. ${ }^{4}$ A three month follow up survey was distributed via email to gather more responses to the journaling process (Table 2 ). The journals were not collected, and residents did not have to share the contents of the journal.

\section{RESULTS}

The overall response rate to the survey was $41 \%$. Thirty-two percent of responding residents journaled before residency and $42 \%$ had used their journal since receiving it at orientation. Residents who journaled reported they "enjoy it" and called it "a good way to reflect." The biggest barriers to journaling were time and/or fatigue ( $59 \%$ of respondents). Regarding burnout, prior to residency, $26 \%$ of responding residents reported feeling burned out from work up to once a month. In comparison, 68\% of responding residents reported they felt burned out from work up to once a month or more (includes survey response options of once a month or less, a few times a month, once a week, a few times a week, or daily).

\section{DISCUSSION}

Through this educational intervention, more residents were exposed to journaling as a way to relieve stress. Based on the open-ended survey question, those who did write in their journals enjoyed the experience. The data also showed that residents found the weekly prompts, which attempted to promote reflection and creative thinking, helpful even if they did not write in their journal.

One limitation of the study was the lack of an in-person meeting to discuss journaling as a means of relieving stress. Reflective writing is a way to express thoughts and emotions on paper. That being said, there does not necessarily need to be a technical structure or "correctness" to the writing. In fact, the writing may have more impact if it reflects one's own self-expression. This should include all writing styles and perhaps even be expanded to include drawings, poetry, song lyrics, or graphic novels. Including many different writing styles into the journal may be a way to expose residents to journaling in a less traditional sense, but may reach more residents who did not feel that traditional reflective writing could be incorporated into their daily routine. A way to overcome this limitation in the future would be to incorporate this discussion into the orientation when the residents first get their journals. As many of the residents found the prompts helpful to reflect on, opening the journal to include more forms of self-expression may increase the number of residents who write in their journal to put their reflection on paper.

Lack of time was the other significant barrier for residents writing in their journal. Residency already diminishes residents' free time and puts a strain on the work-life balance, often contributing to the burnout in the first place. Therefore, adding an additional task for residents is not the intention of this educational intervention. Future directions would include more structured journaling time during residency to increase exposure to journaling. This could be done by incorporating journaling into the already established "intern stress relief" hour that takes place once a month during the noon conference hour. This would expose more residents to journaling as it would take place during a structured hour. 


\begin{tabular}{|c|c|}
\hline \multicolumn{2}{|c|}{ Table 1 } \\
\hline Question & Answer choices \\
\hline $\begin{array}{c}\text { Did you answer last week's } \\
\text { journal prompt? }\end{array}$ & Yes; No \\
\hline $\begin{array}{c}\text { Did you write in your journal } \\
\text { outside of the prompt? }\end{array}$ & Yes; No \\
\hline $\begin{array}{c}\text { What type of rotation are you on? } \\
\text { I feel burned out from my work }\end{array}$ & $\begin{array}{c}\text { Floors; Outpatient; ICU; Elective } \\
\text { Once a month or less; A few } \\
\text { times a month, Once a week; } \\
\text { A few times a week; Every day }\end{array}$ \\
\hline $\begin{array}{c}\text { I have become more callous } \\
\text { toward people since I took } \\
\text { this job }\end{array}$ & $\begin{array}{c}\text { Never, A few times a year or less, } \\
\text { Once a month or less, A few } \\
\text { times a month, Once a week, } \\
\text { A few times a week, Every day }\end{array}$ \\
\hline
\end{tabular}

The strength of this project is the positive response residents who journaled provided regarding the journaling process as a way to minimize burnout. Additionally, this project shows the achievability of getting a journal for each incoming resident and sending a journaling prompt each week. Text message was used to send the prompt as it is typically accessed more readily than email. There was also faculty support. This shows that an ongoing journaling curriculum could be achieved to expose residents each year to journaling as a means of decreasing burnout.

\section{CONCLUSIONS}

As burnout increased from $26 \%$ prior to residency to $68 \%$ at three months into residency, the survey data reaffirms that burnout is a significant issue among incoming Internal Medicine residents. The qualitative responses to the survey showed that residents who journaled found it beneficial. However, more survey data is needed to study the effect of journaling on resident burnout. The data also reflected that lack of time was a main cause of not using the journal. Therefore, a future direction of the project would be incorporating journaling into the resident wellness program.

\begin{tabular}{|c|c|}
\hline Question & Answer choices \\
\hline $\begin{array}{c}\text { Prior to residency did you ever } \\
\text { write in a journal? If so, what was } \\
\text { your experience? }\end{array}$ & Open ended \\
\hline $\begin{array}{l}\text { Since getting your journal at } \\
\text { orientation, how frequently have } \\
\text { you used your journal? }\end{array}$ & $\begin{array}{l}\text { Never; Once every few months; } \\
\text { Once a Month; Once a week; } \\
\text { A few times a week; daily }\end{array}$ \\
\hline $\begin{array}{l}\text { If you used your journal, } \\
\text { what were your thoughts on } \\
\text { journaling? }\end{array}$ & Open ended \\
\hline $\begin{array}{c}\text { If you did not use your journal, } \\
\text { what did you feel was the biggest } \\
\text { barrier to doing so? }\end{array}$ & Open ended \\
\hline $\begin{array}{c}\text { Did you find the weekly prompts } \\
\text { helpful? }\end{array}$ & Open ended \\
\hline $\begin{array}{l}\text { Is there a way other than text } \\
\text { message you would rather receive } \\
\text { the prompt? }\end{array}$ & Open ended \\
\hline $\begin{array}{l}\text { Did you journal outside of } \\
\text { responding to the prompt? }\end{array}$ & Open ended \\
\hline $\begin{array}{c}\text { Prior to residency, how often } \\
\text { did you feel burned out from } \\
\text { your work? }\end{array}$ & $\begin{array}{l}\text { Never; A few times a year or less; } \\
\text { Once a month or less; } \\
\text { A few times a month; Once a week; } \\
\text { A few times a week; Daily }\end{array}$ \\
\hline $\begin{array}{l}\text { Currently, how often do you feel } \\
\text { burned out from your work? }\end{array}$ & $\begin{array}{l}\text { Never, A few times a year or less; } \\
\text { Once a month or less; } \\
\text { A few times a month; Once a week; } \\
\text { A few times a week; Daily }\end{array}$ \\
\hline
\end{tabular}

\section{REFERENCES}

1. Puechl, Allison M. Evaluation of a wellness curriculum as an intervention to decrease burnout among obstetrics and gynecology residents. Obstetrics $\&$ Gynecology. 2015; 126: 40S-41S

2. Runyan, Christine, et al. Impact of a family medicine resident wellness curriculum: a feasibility study. Medical education online. 2016; 21: 30648

3. Williams, Daniel, et al. Efficacy of burnout interventions in the medical education pipeline. Academic Psychiatry. 2015; 39: 47-54

4. West, Colin P., et al. Single item measures of emotional exhaustion and depersonalization are useful for assessing burnout in medical professionals. Journal of general internal medicine. 2004; 24: 1318-21. 